\title{
Moisés sob investigação: Sigmund Freud \\ e o labirinto borgeano
}

Patrícia de Oliveira Leme ${ }^{1}$

RESUMO: Este trabalho objetiva promover uma intersecção entre o texto "Moisés e o monoteísmo”, de Sigmund Freud, e o conto "A morte e a bússola”, de Jorge Luis Borges. O enodamento se constituirá através do cunho investigativo comum a ambos: Borges, através do conto policial e Freud por via da investigação analítica. Em ambos os casos o texto é produzido a partir uma conjectura, afetando a relação do leitor com o texto e impondo-lhe uma reestruturação da leitura em ato.

PALAVRAS-CHAVE: Escritura, judeidade, literatura e psicanálise.

ABSTRACT: This paper aims to provide an interpretative intersection between Sigmund Freud's "Moses and Monotheism” and Jorge Luis Borges’ short story “Death and the Compass” (“La muerte y la brújula”). This entanglement will be built upon the investigative structure that is common to both texts: in Borges, through the detective story, and in Freud, through the analytical investigation. Both texts are constructed by means of a conjecture, which affects the relationship between reader and text and imposes a restructuration of reading into an act.

KEYWORDS: Writing, jewishness, literature and psychoanalysis.

Descubramos, pois, sua pista onde ela nos despista.

(Jacques Lacan)

Ao considerar Sigmund Freud o pai da psicanálise, cabe pensar o que ele deixa àqueles que o sucedem. Se tomarmos o texto "Moisés e o monoteísmo" (1938[2006]) como seu testamento ${ }^{2}$, o que a psicanálise, sua filha dileta, herdaria?

Escrito entre 1934 e 1938, "Moisés e o monoteísmo" se constitui em três ensaios, publicados separadamente ${ }^{3}$. Texto tardio, o penúltimo trabalho de Freud ${ }^{1}$ propõe inicialmente a investigação das origens das religiões monoteístas, tomando o monoteísmo judaico como ponto de partida. Na composição do texto - tido aqui como um testamento - estariam elencados certamente, dentre os bens mais ostentosos de sua herança, uma série de formulações tecidas em quase quatro décadas de produção. No decorrer da leitura testemunhamos o percurso refeito ao mito da horda primeva, o enlaçamento entre filogênese e ontogênese, a face da bruxa metapsicologia. Na proposta de Freud, tais teorizações basais à psicanálise dão contorno à proposição polêmica declarada logo na abertura: “Moisés, um egípcio" é o título do primeiro capítulo5 (1938[2006], p.7).

${ }^{1}$ Mestranda pela Universidade Estadual de Campinas - Campinas. Contato: patricia.oleme@gmail.com.

2 Ou seu textamento, para deixar ouvir o ato falho que insiste pela terceira vez.

${ }^{3}$ Conforme a nota introdutória de James Strachey, o primeiro ensaio foi publicado no começo de 1937, e o segundo ao fim do mesmo ano. O terceiro ensaio foi publicado somente na primavera de 1938, quando de sua mudança forçada à Inglaterra após a ocupação da Áustria pelos nazistas (1938[2006], p.4-5).

4 O último texto de Freud é o “Esboço de psicanálise” (1938[2006]), deixado inacabado e de publicação póstuma em 1940.

5 As citações de Freud presentes nesse artigo são traduções da versão publicada em espanhol pela Amorrortu Editores, cotejadas com o texto em português. 
Atípico ao gênio freudiano, o choque inicial recebe o verniz de uma revisão bibliográfica rigorosa, esta sim mais familiar ao autor. À asserção de abertura segue-se a formulação da hipótese título do segundo capítulo, "Se Moisés era egípcio" (1938[2006], p.17), em uma operação que funda o espaço da dúvida e, simultaneamente, abre caminho para a composição de seu raciocínio. Este é o gesto teórico que alimenta o mecanismo do texto, cujo funcionamento é estabelecido de início pelo hiato entre a constituição da tradição judaica e suas bases históricas - a fuga do Egito e a fundação de sua religião em Canaã. Ao trazer essa polaridade à baila, Freud deixa à psicanálise o compromisso ético com o rigor teórico que, a despeito de seus desdobramentos, constitui-se como fundamental a um campo recém-fundado, que dará seus passos seguintes sem o auxílio de seu criador.

O autor traz à cena o impulso produtivo que, mesmo se submetido a limitações políticas ou mesmo físicas, não se consegue represar. Na conclusão do segundo ensaio, confrontado com tais contingências, o autor deixa em suspenso a hipótese que daria continuidade ao estudo; apesar de ter por sedutora a possibilidade de dar continuidade ao seu trabalho, Freud declara: "Mas desconfio de minhas forças para levá-lo a cabo" (FREUD, 1938[2006], p.51). Passado um ano, já realocado de Viena para Londres em 1938, ele dá seguimento ao seu estudo, gesto que temos por significativo.

Dentre os bens indeléveis que compõem a herança freudiana, esse gesto é algo que parece ínfimo: um singelo brilhante, joia de família, cujo valor só se dimensiona ao sermos familiarizados com sua história. Em meio às grandiosidades de seu legado, "Moisés e o monoteísmo" faz luzir de maneira discreta, mas insistente, a sua relação com o trabalho, a dedicação para com a investigação psicanalítica e a sua atitude em relação ao desenvolvimento teórico, ao espaço da dúvida cavado desde o início do seu percurso e à validade das hipóteses que recobrem esse espaço sem, no entanto, apagá-lo.

O posicionamento de Freud diante da produção do conhecimento lhe permite operar no espaço da dúvida, que abandona seu caráter de empecilho; ao contrário, sua escrita dá contornos aos limites da razão frente à verdade, o que vem a circunscrever uma verdade não-toda e a implicar textualmente os desvios que lhe dão contorno. Como autor, Freud não é senhor em seu próprio texto ${ }^{6}$, posição que institui o saber psicanalítico como transmíssivel também por via de um estilo ${ }^{7}$. Ao cavar caminhos nos desvios encontrados ao longo de "Moisés e o monoteísmo", Freud confere a seu texto um funcionamento que estruturalmente impossibilita a apreensão total de seu objeto, cuja organicidade se revela em seguimentos paralelos sem promessas de homogeneização. Pelo contrário, a questão inicial - a busca pelas raízes do monoteísmo - dá lugar ao estudo do monoteísmo judaico, sustentado como a derivação de uma fase passageira da

${ }^{6}$ Segundo Freud: "Mas, desgraçadamente, a força criadora de um autor nem sempre obedece à sua vontade; a obra sai da melhor maneira possível, e frequentemente se contrapõe ao autor como algo independente, e mesmo alheio." (FREUD, 1938[2006], p.101).

${ }^{7}$ Antônio Quinet afirma que a transmissão de aquilo que é transmissível na psicanálise se dá, também, por via de um estilo, que leva o sujeito a produzir uma verdade com base em um saber (2009, p. 57-58). A maneira pela qual Freud consegue com que o leitor seja implicado em "Moisés e o monoteísmo" será abordada posteriormente.
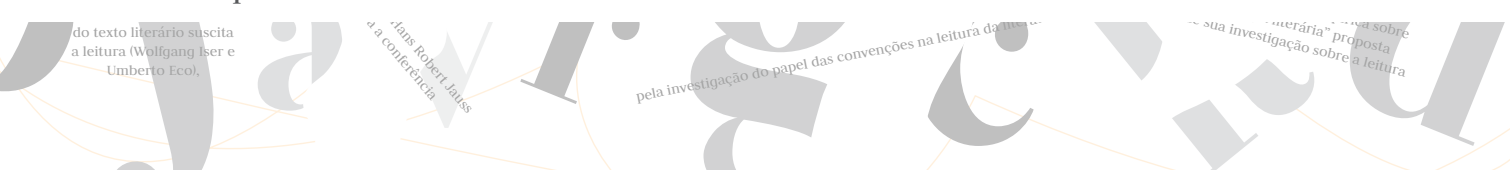
história do Egito ${ }^{8}$. Antecipando a possível crítica, Freud traz um questionamento acerca do proveito desse desvio para refutá-lo de maneira lapidar, estabelecendo que no caso do seu texto "não se trata de ganho, mas de investigação" (FREUD, 1938[2006], p.63-64).

Tal asserção nos vem como chave de leitura para "Moisés e o monoteísmo", podendo ser estendida à totalidade da obra freudiana. Com Freud, o objeto de estudo deixa de ser o objetivo do texto, e passa a ser delineado por sua própria tessitura ${ }^{9}$. Levando em conta o método freudiano e a abordagem que o autor faz do judaísmo, é curioso que encontremos similitudes em um conto de Jorge Luis Borges, que narra uma investigação iniciada pela morte de um rabino:

O senhor replicará que a realidade não tem a menor obrigação de ser interessante. Eu lhe responderei que a realidade pode prescindir dessa obrigação, porém não as hipóteses. Naquela que o senhor improvisou, intervém copiosamente o acaso. Eis aqui um rabino morto; preferiria uma explicação puramente rabínica, não os imaginários percalços de um imaginário ladrão. ${ }^{10}$ (BORGES, 1975, p.135)

\section{As pistas de Borges}

A citação acima refere-se a uma fala de Erik Lönnrot, detetive da linhagem de $\mathrm{Au}^{-}$ guste Dupin e personagem central do conto “A morte e a bússola”, de Jorge Luis Borges. Publicado pela primeira vez em 1944, o conto narra o trajeto do detetive Lönnrot em busca de um assassino serial, cujos rastros são tomados como uma trama religiosa, envolvendo uma suposta seita judaica que busca o nome secreto de Deus. A trama que o detetive passa a deslindar se revela, ao fim do conto, como o labirinto que o leva a sua própria morte, arquitetado pela sede de vingança de Red Scharlach.

Na primeira cena do crime, base para a construção do labirinto, o Doutor Marcelo Yarmolinsky é encontrado morto, apunhalado no peito. A morte do rabino, instalado no Hôtel du Nord para participar do Terceiro Congresso Talmúdico, gera uma conjectura inicial de que ali se encontrava o resultado de um roubo malsucedido em que o

Freud propõe, com base em estudos historiográficos, que o Egito passou por uma fase monoteísta, que tem fim juntamente com o reinado de seu fundador, Ikhnatón. De acordo com a proposição freudiana, Moisés foi uma pessoa do alto escalão egípcio, cuja personalidade forte possibilitou a libertação dos escravos do Egito que, após a unificação com outros povos em Qadesh, veio a se tornar o povo hebreu. Freud conjectura que Moisés seria partidário à religião de Ikhnatón, e a instaura após o abandono do Egito.

${ }^{9}$ Segundo Betty Fuks, "Freud, como iconoclasta, remete o pensar psicanalítico para um mais além, movido pelo desejo da diferença e ciente de que qualquer ganho de saber incorpora e cria o icognoscível. (...) Este é o movimento, de que fala Lévinas, de não retorno ao Mesmo. o gesto ético de Freud é também o de Moisés, o egípcio, conforme seu próprio texto Moisés e o monoteísmo, ou o do judeu que nunca termina de empreender o êxodo, de atravessar o deserto"; e mais adiante, "[A antiidolatria a um saber finito e totalizante] é o esforço que obriga o analista a travessar os afetos e as ideias como nômades atravessam o deserto e as cidades" (2000, p.104).

10 “Usted replicará que la realidad no tiene la menor obligación de ser interesante. Yo le replicaré que la realidad puede prescindir de esa obligación, pero no las hipótesis. En la que usted ha improvisado, interviene copiosamente el azar. He aquí un rabino muerto; yo preferiría una explicación puramente rabínica, no los imaginarios percances de un imaginario ladrón” (BORGES, 1996, p.8).
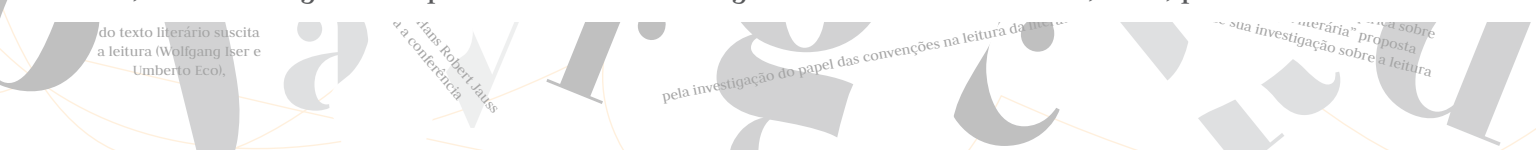
ladrão silenciara sua testemunha. Erik Lönnrot dá, então, o primeiro passo em direção ao dédalo que contará com outros dois assassinatos para sua construção: "É possível, mas não interessante" ". Ignorando a solução provável, o detetive se propõe elaborar uma morte que se integre à tradição judaica. Para retomarmos a citação anterior, "O senhor replicará que a realidade não tem a menor obrigação de ser interessante. Eu lhe responderei que a realidade pode prescindir dessa obrigação, porém não as hipóteses". O conto começa, então, a tomar outras proporções.

Lönnrot dá como primeira pista um rascunho, ainda preso à máquina de escrever, no qual consta escrito "A primeira letra do Nome foi articulada" (BORGES, 1975, p.136) Esta cena inicial institui as linhas investigativas a serem traçadas pelo detetive, cuja suposição é justificada pelos dois crimes subsequentes, que contam com a mensagem enigmática: "A segunda letra do Nome foi articulada" e finalmente "A última das letras do Nome foi articulada". Hebraísta recente e puro raciocinador, o detetive não se deixa iludir pela estrutura tríplice: três letras do Nome articuladas, cada uma no dia 03 do mês, em locais que formam um triângulo equilátero. O quarto lugar, onde acontecerá o quarto crime $^{13}$ no próximo dia 04 , foi corretamente inferido, culminando em sua morte.

O conto de Borges traz à cena uma distorção do gênero policial. Neste caso, as pistas não remontam o crime, mas operam em sua montagem. Diferentemente dos textos mais comuns do gênero, nos quais se faz necessário recolher e analisar as pistas ao longo da narrativa para se chegar ao fato, em "A morte e a bússola" é a pista primeira que dá origem aos crimes subsequentes: o que havia sido de fato uma morte acidental, crime no qual "intervém copiosamente o acaso", é transmutado em uma complexa estrutura criminosa, que promove sacrifícios humanos para encontrar o nome de Deus. O rascunho do rabino é tomado como evidência por Lönnrot, o que possibilita a Red Scharlach a tessitura de sua armadilha. O crime perseguido pelo detetive, de fato, não ocorreu; ele passa a ter ocorrido no processo de sua investigação ${ }^{14}$.

Esta torção é notada por Ricardo Piglia, em suas "Teses sobre o conto" (2004). Partindo de sua tese principal, na qual reza que "um conto sempre conta duas histórias" (PIGLIA, 2004, p.89), Piglia se propõe um exercício ensaístico ao analisar o estilo de grandes contistas através do manejo que se faz delas, bem como das relações que se estabelecem entre a primeira e a segunda história. No caso de Borges, "a história 1 é um gênero e a história 2 é sempre a mesma (...) A variante fundamental que Borges introduziu na história do conto consistiu em fazer da construção cifrada da história 2 o tema do relato" (PIGLIA, 2004, p.93).

Piglia nota que a estrutura do conto borgeano, tomando "A morte e a bússola" como base de sua tese, transparece propositalmente aquela história não dita, narrada

11 "Posible, pero no interesante" (BORGES, 1996, p. 8)

12 "La primera letra del Nombre ha sido articulada” (BORGES, 1996, p. 8).

${ }^{13}$ Conforme esclarece o personagem Red Scharlach, "essa passagem dá a entender que as mortes ocorreram no quarto dia de cada mês" (BORGES, 1975, p.146). No original: "ese pasaje manifiesta que los hebreos computaban el día de ocaso a ocaso; ese pasaje da a entender que las muertes ocurrieron el cuatro de cada mes." (1996, p. 16).

${ }^{14}$ Esta estrutura sintática foi proferida em aula pela Profa Dra Nina Leite, para explicar o conceito de trauma para a psicanálise: uma situação não é traumática em si, mas passa a ter sido traumática aprés-coup.

r
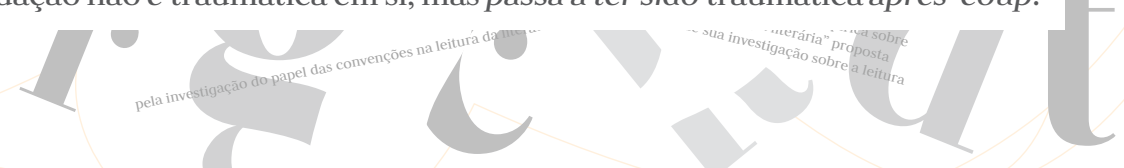
através do que é dito. Ciente do inevitável emergir de uma história outra, Borges a insinua e utiliza essa condição constituinte do conto como mecanismo de sua escritura.

O ensaísta faz ainda uma suposição que devemos observar de perto: "Em 'A morte e a bússola', a história 2 é uma construção deliberada de Scharlach” (PIGLIA, 2004, p.93). Há, de fato, a emersão de uma segunda história, a partir da qual a narrativa abandona seu caráter de investigação e passa a ser uma trama de vingança, na qual o protagonista, no auge de sua hýbris, se enreda. Neste caso, a história 1 seria a da investigação virtuosa de Lönnrot, e a história 2, a da armadilha arquitetada pelo criminoso. Apesar de coerente, esta leitura subestima um elemento crucial ao conto, o qual tomamos também como base para a leitura que aqui se desenvolve. A trama de Scharlach é assimilada à primeira história, e pode ser observada inteiramente em uma segunda leitura - o que não deixa de ser, por si só, um movimento deveras sofisticado.

Tendo início com uma trama investigativa que, ao final, revela-se como a construção desta trama, "A morte e a bússola" nos traz como história 1 o próprio gênero policial, que nos chega com um mistério a ser racionalizado e organizado logicamente; ao nos revelar o funcionamento do crime que passou a ter ocorrido, o conto nos traz o avesso do gênero, o qual possibilita ao leitor entranhar-se no funcionamento do texto. A história 2, aquela de que Borges faz "tema de seu relato" (PIGLIA, 2004, p.93), é o gesto de colocar em ato do próprio mecanismo do conto policial, no qual o crime é visto por dentro e o inquérito é simultâneo à sua conclusão.

Esta leitura se sustenta, também, por um discreto deslocamento de foco narrativo. Em um único momento do texto, o narrador faz uso da primeira pessoa; o que está em jogo não é, no entanto, somente o uso da primeira pessoa, mas o que ele postula:

\footnotetext{
- Exatamente porque planejam um quarto crime, podemos ficar tranquilos. Lönrrot pendurou o fone. Uma hora depois, viajava num trem das Ferrovias Austrais, rumo à quinta abandonada de Triste-le-Roy. Ao sul da cidade de meu conto, flui um obscuro riacho de águas barrentas, infestado de curtumes e de imundície. ${ }^{15}$ (BORGES, 1975, p.141, grifo da autora)
}

A partir desta afirmação, o conto abre-se em uma segunda estrutura dual. O narrador emerge como escritor do conto no próprio ato de leitura, e escancara a realidade da narrativa como ficcional. O efeito de tal artifício, longe de afastar o leitor, o enlaça ainda mais. O leitor se surpreende como leitor, para a posteriori se flagrar em um labirinto biaxial: ele é capturado tanto na armadilha de Scharlach, junto com Lönnrot, quanto no texto-labirinto que o narrador tece. Desta forma, o texto promove uma situação na qual o leitor está duplamente implicado.

Somado à convergência entre os métodos investigativos, iluminada pelas citações de Freud e de Borges, e à eleição da tradição judaica como tema, este movimento promovido por Borges pode funcionar como um ponto de articulação entre "A morte e a

15 “Precisamente porque planean un cuarto crimen, podemos estar muy tranquilos - Lönnrot colgó el tubo. Una hora después, viajaba en un tren de los Ferrocarriles Australes, rumbo a la quinta abandonada de Triste-le-Roy. Al sur de la ciudad de mi cuento fluye un ciego riachuelo de aguas borrosas, infamado de curtiembres y de basuras" (BORGES, 1996, p. 12, grifo da autora).
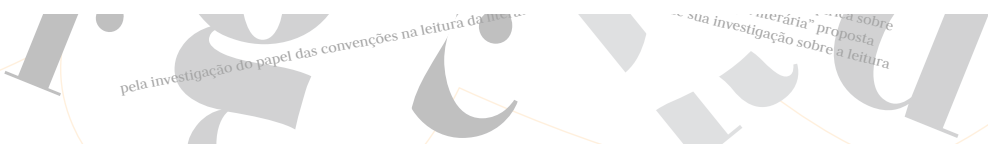
bússola" e "Moisés e o monoteísmo". O conto se revela posteriormente como uma arma de Scharlach para atingir seu inimigo: trata-se de um punhal fundido para ferir uma única pessoa, somente aquela que, dentre todos os envolvidos no inquérito, se deixaria enredar. Lönnrot realiza seu objetivo e conclui o caso através de uma investigação que passa pela tradição judaica; porém, a resolução do caso lhe escapa, o que o leva a uma conclusão outra, possibilitada pelo desenrolar de sua investigação. No texto de Freud, vemos também um movimento investigativo que caminha para a solução do problema estabelecido, mas simultaneamente o trama ao longo do texto. Para que se atravesse "Moisés e o monoteísmo", o leitor é impelido a envolver-se na investigação proposta por Freud $^{16}$. Os meandros do texto também tragam o leitor, envolvendo-o no ardil que o autor parece tecer para si mesmo.

\section{Freud à la Dupin: a investigação psicanalítica}

Através da leitura de "A morte e a bússola" é possível tecer alguns questionamentos sobre "Moisés e o monoteísmo": observando o método investigativo de Freud, cabe perguntar como o leitor estaria implicado, como ele é chamado a percorrer o texto. Ou mesmo, estendendo livremente a tese de Piglia a esse texto teórico, haveria uma segunda história que a tessitura freudiana dá a ver? No caso, o que o funcionamento textual de "Moisés e o monoteísmo" nos permite dizer sobre a investigação psicanalítica?

Como Freud, começamos com uma hipótese: tomando a construção do crime no conto borgeano, que se revela como sendo o próprio mecanismo de sua escritura, captura-se algo que se institui em um processo de retroação, sustentado a partir da própria construção do texto. Freud inicia sua investigação com uma pista, uma evidência tomada como fio condutor logo na primeira página de seu texto. $\mathrm{O}$ ato de tomar por ponto de partida um fato de verificação impossível, e de dá-lo a ver sem qualquer preâmbulo, precipita uma organização textual particular; é justamente esse caráter esquivo ao resto da produção freudiana que gera nossa questão, bem como a sustenta ${ }^{17}$. Isso porque, assim como Freud e como Lönnrot, partimos de um problema que vem se delineando: o enodamento entre o exercício de um método em "Moisés e o monoteísmo" e o funcionamento textual, em uma ação investigativa particular pela qual Borges nos desvela a construção do conto no ato de leitura.

Como assinala o autor, na advertência preliminar do terceiro ensaio, "Perante a minha crítica, esse trabalho que toma Moisés como ponto de partida aparece como uma bailarina que se equilibra sobre a ponta de um pé” (FREUD, 1938[2006], p.56). Freud sustém o frágil

${ }^{16}$ Para que se percorra o texto, Freud muitas vezes pede uma posição também investigativa do leitor, que se apoia nas hipóteses construídas pelo autor para sua própria investigação: “Talvez não tenhamos obtido mais que uma certa verossimilhança. Mas supomos ter alcançado a demonstração plena” (FREUD, 1938[2006], p.123, grifos nossos).

${ }^{17}$ Cremos que esse gesto particulariza “Moisés e o monoteísmo" entre os demais textos de Freud. Em “Totem e Tabu” (1913), por exemplo, o autor parte do fato da coincidência da proibição do incesto em qualquer sociedade. Em “O mal estar na cultura" (1929) e "Futuro de uma ilusão" (1927), apesar de temática e cronologicamente subsequente a "Além do príncípio de prazer” (1920), a controversa questão do fusionamento pulsional e da pulsão de morte é mais uma vez lentamente traçada.

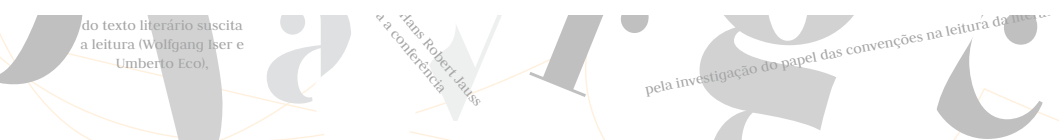


equilíbrio de seu edifício por um longo percurso, através de outras evidências sustentáveis mais pela coerência do que por um suposto caráter verídico: a primeira evidência de que Moisés seria egípcio é dada pela inversão do seu nome. Mosche é tomado pela tradição escrita e oral como "o recolhido das águas", quando a etimologia mais precisa seria sua forma ativa, "aquele que recolhe" (FREUD, 1938[2006], p.8). A inversão do nome autoriza o próximo passo, que enxerga no mito mosaico a leitura invertida da saga do herói.

Se retomarmos a imagem do labirinto que a leitura de "A morte e a bússola" nos deu, pode-se dizer que Freud sabia estar tecendo sua tese por via de um método investigativo peculiar:

Se não se podia alcançar uma certeza maior, por que dar publicidade à minha indagação? Lamento ter que me limitar aqui, para justificar o meu proceder, a meras indagações. E elas são: se alguém se deixa levar pelos argumentos assinalados e experimenta levar a sério a suposição de que Moisés era um egípcio nobre, ele obterá algumas perspectivas muito interessantes e amplas. (FREUD, 1938[2006]), p.15)

Não há que se considerar, no entanto, que Freud conhecia com exatidão as veredas de seu próprio texto. A citação acima põe em vigor a amplitude que sua hipótese pode alcançar, e levará o autor a retomar sua famosa tese de "Totem e Tabu" (1913). O mito da horda primeva é, no entanto, percorrido novamente a partir do eixo mosaico, o Grande Homem assassinado ao assumir o lugar de Pai para um povo. Se a teorização que estabelece a religião como uma neurose da humanidade já havia sido formulada, Freud a atravessa novamente, partido desta vez não de um fato saliente em qualquer sociedade, mas de uma tese obscurecida pela distância temporal, iluminada modestamente por estudos historiográficos. Chamamos atenção aqui não só para o conteúdo da conjectura, mas para o fato de ela se constituir irrevogavelmente como uma conjectura, a qual, uma vez estabelecida a priori na investigação freudiana, promove um efeito distinto dos seus demais textos sobre a cultura. O labirinto freudiano inclui, então, seu próprio idealizador a errar por seus caminhos.

À trágica captura de Lönnrot alinha-se, pela natureza de sua busca, novamente o leitor. Implicado em uma estrutura textual instituída inicialmente em um vazio, o leitor prossegue, juntamente com Freud, na busca de uma solução impossível. Com Lönnrot, buscamos o nome impossível de Deus, a quarta letra que nos dará a verdade de nossa investigação. A trama investigada, e a rigor também tecida, pelo detetive é levada às últimas consequências, culminando no zênite de sua vida: a verdade alcançada não só o leva à morte, mas é, com efeito, sua própria morte. É irônico que Lönnrot seja levado a tal ponto por meio da investigação de um assassinato "possível, mas não interessante", já que isso lhe garante uma morte que ele próprio idealizara.

O movimento freudiano em "Moisés e o monoteísmo", podemos pensar, leva o pai da psicanálise a um ponto limite de seu percurso teórico. Ao propor uma leitura da tradição judaica pelas vias abertas em “Totem e Tabu”, o autor também se coloca à revelia de um destino funesto; se escapara de complicações políticas ao mudar-se para Londres, em sua segunda advertência preliminar ao terceiro ensaio, Freud declara ter ciência de que poderia perder as simpatias da Igreja Católica, que deu guarita ao autor e a seus discípulos
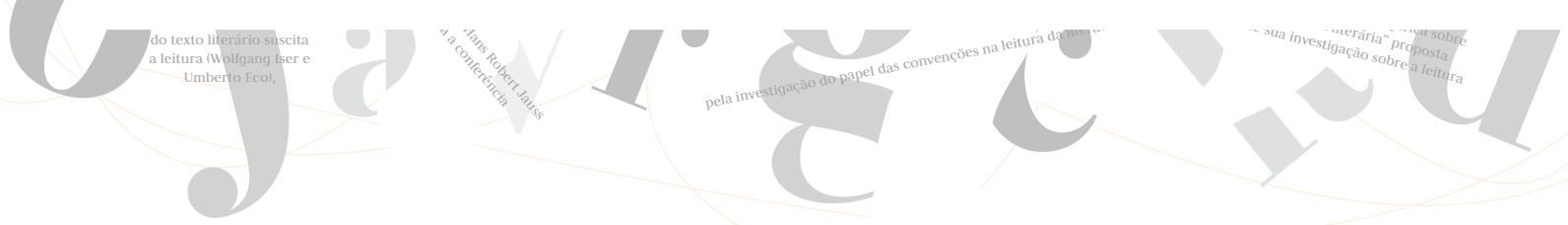
no período de instabilidade na Áustria ${ }^{18}$. Ao levar a cabo sua publicação, já na Inglaterra, Freud o faz porque "já não há mais dissuasivos exteriores, ou ao menos não aqueles diante dos quais é preciso retroceder" (1938[2006], p.55). Freud, no entanto, conhecia o risco do ostracismo, tanto por parte da comunidade judaica quanto de seus atuais compatriotas. Como acontece com Lönnrot, o destino nefasto traça-se pelo fato de Freud não recuar, sendo essa uma postura que sustém o compromisso com a teoria psicanalítica até seu ponto nodal: o lógos é levado, em ambos os casos, às últimas consequências. A morte, no caso de Lönnrot, e o ostracismo, no caso de Freud, são punições trágicas por excelência, preço pago pelo sublime da criação literária e da produção do saber psicanalítico.

É também nessa direção que Betty Fuks (2000) aborda o texto freudiano. "Moisés e o monoteísmo" é marcado pelo que chamou de ateísmo da escrita, que no texto de Freud se estabelece através da desmaterialização de Deus (FUCKS, 2000, p. 99-100). A ausência radical de qualquer representação divina, causa motriz de um avanço cultural possibilitado pelo judaísmo ${ }^{19}$, não se introduz no texto sem consequências; ao contrário, com a instituição da ausência inalienável de Deus na estrutura teórica de "Moisés e o monoteísmo", evidencia-se que a hipótese primeira, bem como as subsequentes, podem ser lidas a partir de um esvaziamento estrutural da escrita, ou mesmo da linguagem. Como aponta Fuks, "Moisés e o monoteísmo" contribui de maneira ímpar através desse movimento:

\begin{abstract}
Pode-se dizer que a complexidade do derradeiro texto freudiano sobre a cultura renova, de uma maneira surpreendente, a leitura psicanalítica sobre a ideia de Deus. Ao introduzir a noção de verdade histórica designando-a como uma multiplicidade de traços e de inscrições que se re-atualizam, incessante e diferencialmente, a ideia de Deus ganha na teoria freudiana o estatuto de uma operação textual. (FUKS, 2000, p.57)
\end{abstract}

O esvaziamento da ideia de Deus, a proibição de seu nome, impossibilita qualquer caminho que leve a um postulado imutável. Como podemos inferir a partir da citação de Fuks, a própria estrutura de "Moisés e o monoteísmo" já implica essa ausência, pois parte de uma suposição que não se pode postular: ela escapa pelas lacunas obscurecidas pela história, às quais só se tem acesso através das desfigurações da tradição judaica. Freud organiza sua tese nos pontos em que o pensamento historiográfico dá por limite: é onde acabam as pistas da historiografia que Freud enxerga as suas evidências. Quando "A última das letras do Nome foi articulada" e o caso se encerra, Freud prossegue, juntamente com seu leitor, na busca da verdade. Nesse sentido, Quinet aponta que algo do saber psicanalítico é transmissível, também, por um estilo. Para o autor,

A psicanálise ensina que o Inconsciente tem um estilo tributário da instância da letra que diz respeito à verdade do sujeito manifesta no retorno do recalcado submetido

18 “Naquele tempo eu vivia sob a proteção da Igreja Católica e com a angústia de perdê-la com a minha publicação e provocar, para os seguidores e discípulos da psicanálise, uma proibição de trabalhar na Áustria" (FREUD, 1938[2006], p. 55).

${ }^{19}$ Segundo Freud, a religião judaica “obrigou o povo a progredir na espiritualidade, o que, já bastante significativo por si só, inaugurou também o caminho rumo à alta estima pelo trabalho intelectual e a ulteriores renúncias pulsionais" (1938[2006], p.119).

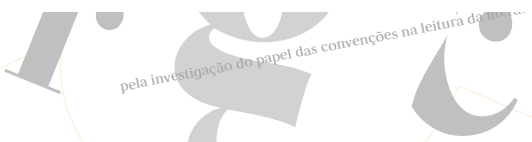


aos desfiladeiros do significante. Assim, um ensino de psicanálise digna de Freud só se produzirá pela via de um estilo: "por onde a verdade mais escondida se manifesta nas revoluções da cultura”. (QUINET, 2009, p. 57-58)

Através do caráter irremediavelmente lacunar do objeto de "Moisés e o monoteísmo", elaboração teórica cuja construção se estabelece até o fim por via dessas mesmas lacunas, Freud erige um texto que leva o sujeito a envolver-se na produção de maneira inevitável. Como coloca Quinet, o estilo de Freud é tributário à instância da letra, cujo esforço é de alhear à teoria psicanalítica a estabilização dos sentidos, e a proposta de dominar uma verdade plena. A escritura freudiana se coloca na contracorrente do discurso científico - no trabalho de afastar do texto a carga imaginária que o significante pode adquirir. É nesse aspecto que a disjunção entre verdade e saber torna-se essencial ao campo psicanalítico, o que podemos observar de maneira singular em "Moisés e o monoteísmo". Pois, nesse texto, Freud parte do limite do que a historiografia pode dizer, produzindo um saber a partir de seus furos. São justamente estes furos, cristalizados na condicional "Se Moisés era egípcio", que dão funcionalidade ao texto de Freud, e confrontam o leitor com os limites do simbólico. Como tão bem aponta Quinet, parafraseando Lacan,

\footnotetext{
é colocado em jogo no ensino da psicanálise não o trabalho de transferência $(\mathrm{a} \rightarrow \$)$, e sim a transferência de trabalho $\left(\$ \rightarrow S_{1}\right)$, em que o ensinante dividido por uma questão $(\$)$ endereça sua elaboração de saber àquele $\left(\mathrm{S}_{1}\right)$ que ele pretende que produza também um saber $\left(\mathrm{S}_{2}\right)$, como na estrutura do discurso da histeria. (QUINET, 2009, p. 55-56)
}

Onde Lönnrot se enreda na ânsia de verdade última, possibilitada pelo seu conhecimento da letra que lhe escapava, é onde Freud avança. Justamente por trazer ao seu texto a consciência de que o labirinto não está só sendo percorrido por ele, mas que ele o está construindo em um movimento simultâneo, é que se dá conta de que o saber buscado no texto terá limite nos seus próprios limites - os do Simbólico frente ao Real ${ }^{20}$. A emersão da verdade do sujeito, no entanto, é propiciada não só pela tessitura teórica, mas pelo funcionamento do texto. Talvez possamos ler nesse mecanismo uma segunda história que "Moisés e o monoteísmo" nos conta: a verdade produzida pelo ato de leitura do leitor, atravessado constantemente ao longo do texto por uma verdade não-toda.

\section{À guisa de conclusão: uma contribuição}

A psicanálise herda do textamento freudiano o exercício de um método, um saber que se efetiva ao permitir ao sujeito a produção de uma verdade. "Moisés e o monoteísmo” é um texto sem saída: ou o leitor se põe a percorrê-lo sem ganâncias de apreen-

20 Conforme Fuks, “Moisés e o monoteísmo é finalmente o produto de uma prática clínica que jamais se curvou a verdades apriorísticas, porque sempre esteve radicalmente fundada no exercício de escuta da inesgotável melodia pulsional. Nessa perspectiva, pode-se dizer que, ao formalizar o conceito de verdade histórica nesse seu derradeiro texto sobre a cultura, Freud mais uma vez força seu pensamento a ir além dos limites que lhe foram impostos" (FUKS, 2000, p.143-144).
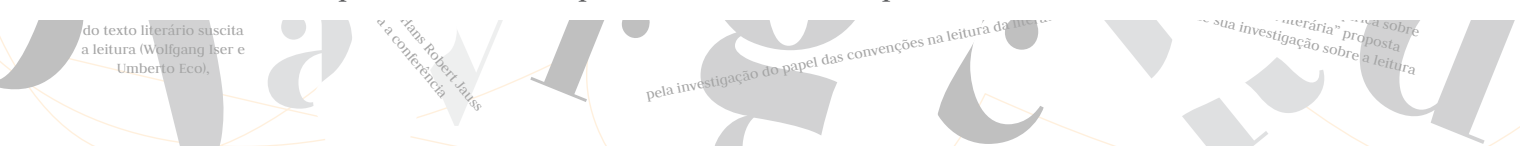
dê-lo completamente, ou é melhor retornar à entrada, enquanto ainda não se deixou levar por sua sinuosidade. Trata-se de um convite deliberado à produção, ao prazer do trabalho intelectual: "não se trata de ganho, mas de investigação" (FREUD, 1938[2006], p.63-64). Aqueles que chegam ao fim, se é que há fim, ganham o percurso, e as possibilidades insondáveis de outros percursos possíveis.

Freud opera em um movimento simultâneo, talvez até contraditório: com extremo rigor, o autor segue as pistas por ele criadas, e as organiza em um texto, grande prosador que é, trabalhando em organizá-las com coerência. Talvez seja esse o labirinto que Lönnrot desejou: "eu sei de um labirinto grego que é uma linha única, reta. Nessa linha perderam-se tantos filósofos que bem pode perder-se um mero detetive"21. O labirinto em linha reta pode ser visto como um só depois do texto freudiano; e, por ser uma linha reta, não se deve omitir que é constituído por uma quantidade infinita de pontos.

Obviamente este exercício de leitura ainda deixa muitos pontos em aberto, e se finda aqui com resignação. Como Lönnrot, que antes de chegar ao significante velado atinge o limite de sua vida, espera-se com esta conclusão uma nova morte em um outro labirinto. Até lá, uma contribuição, como finaliza Freud, foi tudo o que pudemos oferecer.

\section{Referências Bibliográficas}

BORGES, J.L. "La muerte y la brújula”. In: Antología personal. Buenos Aires: La Biblioteca Argentina, 2001.

. “A morte e a bússola”. In: Ficções. São Paulo: Círculo do Livro, 1975.

FREUD, S. "Moisés y la religión monoteísta" (1939[1937-39]). In: Obras completas. Buenos Aires: Amorrortu editores, 2006, vol. 23.

FUKS, B. Freud e a judeidade - a vocação do exílio. Rio de Janeiro: Jorge Zahar Ed., 2000. PIGLIA, R. “Teses sobre o conto”. In: Formas Breves. São Paulo: Companhia das Letras, 2004. QUINET, A. A estranheza da psicanálise - A escola de Lacan e seus analistas. Rio de Janeiro: Jorge Zahar Ed., 2009.

ARTIGO RECEBIDO EN: 19 ago. 2012

ARTIGO ACEITO EV: 12 set. 2012

ReferênCIA eletrônica: LeME, Patrícia de Oliveira. Moisés sob investigação: Sigmund Freud e o labirinto borgeano. Revista Criação \& Crítica, n. 9, p. 200-209, nov. 2012. Disponível em: <http://www.revistas.usp.br/criacaoecritica>. Acesso em dd mmm aaaa.

21 “yo sé de un laberinto griego que es una línea única, recta. En esa línea se han perdido tantos filósofos que bien puede perderse un mero detective” (BORGES, 1996, p. 16).

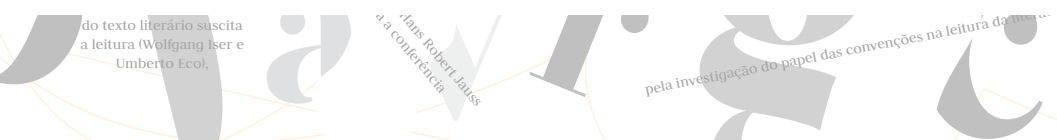

